\title{
Electronic Source Document
}

National Cancer Institute

\section{Source}

National Cancer Institute. Electronic Source Document. NCI Thesaurus. Code C142535.

An original record containing digital data. 